\title{
Reliabitily study (test-retest) of the Scale for Conception of Disability (SCD)
}

\author{
Lúcia Pereira Leite ${ }^{1}$ \\ Hugo Ferrari Cardoso ${ }^{1}$ \\ ${ }^{1}$ Universidade Estadual Paulista (UNESP). Bauru, SP, Brasil.
}

\begin{abstract}
This article describes the reliability of the test-retest of the Scale for Conception of Disability (SCD), which comprehends four dimensions - biological, social, metaphysical and historical cultural - through the analysis of its temporal stability. In this study, a sample of 52 students from a public university of the State of São Paulo completed the same instrument with 30-day-interval between one another. For rating the stability, the Pearson correlation coefficient was used. In terms of total sample, the results of the SCD, as a whole, presented a correlation of strong magnitude $(\mathrm{r}=0,77)$ between test and retest. According to the results, the reliability of the scale was considered appropriate, recommending its use in studies that aim to find out how social groups conceive the disability, understanding that such conception guides the attitudes of society towards people in this condition.
\end{abstract}

Keywords: reliability; scale; conception; person with disability; test-retest.

\section{Estudo de confiabilidade (teste-reteste) da Escala Concepções de Deficiência (ECD)}

\section{Resumo}

Este artigo traça uma síntese sobre concepções de deficiência circulantes nos discursos sociais e descreve a confiabilidade testereteste da Escala Concepções de Deficiência (EDC), que abrange quatro dimensões - biológica, social, metafísica e histórico cultural -, pela análise de sua estabilidade temporal. No estudo, uma amostra de 52 estudantes de uma universidade pública do Estado de São Paulo preencheu o mesmo instrumento, em duas oportunidades, com intervalo de trinta dias. Como medida de estabilidade, foi usado o teste de correlação de Pearson. Em termos da amostra total, os resultados da ECD, em sua totalidade, apresentaram correlação de magnitude forte $(\mathrm{r}=0,77)$ entre o teste e o reteste. De acordo com os resultados, a confiabilidade da escala foi considerada adequada, indicando sua utilização em estudos que procurem conhecer como grupos sociais concebem a deficiência, entendendo que tal concepção norteia as atitudes da sociedade diante das pessoas que se encontram nessa condição.

Palavras-chave: confiabilidade; escala; concepção; pessoa com deficiência; teste-reteste.

\section{Estudio de confiabilidad (test-retest) de la Escala Concepciones de Discapacidad (ECD) \\ Resumen}

Este artículo describe el estudio de confiabilidad test-retest de la Escala de Concepciones de Discapacidad (ECD) que presenta cuatro dimensiones - biológica, social, metafísica e histórica cultural - por medio del análisis de su estabilidad temporal. En este estudio fue utilizada una muestra de 52 estudiantes de una universidad pública del estado de San Pablo, que completaron el mismo instrumento con un intervalo de 30 días entre ellos. Para clasificar la estabilidad temporal fue utilizado el coheficiente de correlación de Pearson. Sobre la muestra total, el resultado de la ECD presentó correlación de magnitud fuerte (.77) entre el test y el retest. De acuerdo con los resultados, la confiabilidad de la escala fue considerada adecuada, recomendando su utilización en estudios que quieran descubrir como los grupos sociales entienden la discapacidad, siendo que esa concepción nortea las actitudes de la sociedad en relación a las personas con esas condiciones.

Palabras clave: confiabilidad; escala; conception; discapacidad; teste-reteste. 


\section{Introduction}

The relationship established with people with disability has quite varied throughout history, emphasizing that each period lived by humanity is marked by different conceptions of disability. Freitas and Marques (2010), while doing a historical analysis of the main interpretations of disability that still perpetuates at the present, established a typology which allows the characterization of different ways of understanding the phenomenon. The authors divided the conceptions into three main arrays of interpretation about the most occurring disability in the analyzed literature: a) disability seen as abnormality, deviation, disease centered on the individual (biological conception); b) conception that shifts the disability from an individual problem to a social issue (social conception); and c) disability seen as spiritual phenomenon marked by the demonstration of wishes or divine punishments, which would characterize feelings of charity or compassion towards disabled people (metaphysical conception).

In order to discuss these arrays, we sought to study Baleotti and Omote (2014), where they report that with the advance of medicine, from the sixteenth century, disability ceased to be considered a religious problem and began to be defined as a medical issue. Then the organicism and/or biological view of disability was strengthened, indicating a trend to locate it in the individual. Despite being questioned, this conception of disability still occurs in health care and education. Understanding disability as such implies actions exclusively focused on the person who is supposed to have this condition.

Opposing to the medical model, the authors highlight the social model of disability in which it is conceived as a result of interpretation of the social environment. In a text which presents a wide review of the social concept of disability, Piccolo and Mendes (2015) point that, in the capitalism, the lesion exceeds their organic nature and change itself into disability, being socially re-signified. In this model, disability does not arise with someone's birth or sickness, but it is created and maintained by society, the same way as the reaction of the public towards individuals will determine whether or not they will be identified as disabled. The public, therefore, is characterized as an integral and critical part of the phenomenon of disability itself (Mike, 2013).

The third model associates disability with spiritual, religious and/or metaphysical causes. Such ideas were highlighted by Pessotti (1984), in his known book Deficiência Mental (Mental Disability): from superstition to science, it alludes to the fact of understanding disability as a metaphysical and spiritual phenomenon, by transcending human, supernatural responsibility. Such thought began in the medieval period when the person in this condition was considered a devil soul. As a result of that thought, charity and compassion are considered legitimate ways of dealing with disabled people (CarvalhoFreitas, 2012). Redeeming this concept is important because, even after centuries, many people still attribute the disabilities to divinity, whether from congenital nature - malformations, syndromes etc - or acquired, such as industrial or automobile injuries, for example.

When associating such propositions with the concepts of disability, previously described, we notice that society still holds a very individual approach (due to organic or social causes), because they focus the disability on the subject, and based on that, they expect the person to fit into social environment.

Subsidized in the cultural-historical psychology, it presupposes the creation of a fourth conception of disability: the cultural-historical conception. The explanation for its creation is given by the need to include the concept of disability in a broader sphere, namely the process of concept formation, which is built on the relation of the meaning of the word, once the construction of the disability concept strives in cultural concepts that are valued at a given historical moment. Leite (2017), while revisiting the work The Fundamentals of defectology, from Vygostki (1997), indicates that the cultural-historical conception interprets disability as dynamic, relational and procedural, based on the relationship between individual and socio-cultural context, leading to a differentiated human development, adjustable in accordance to the expectations and attitudes directed to the individual. The author defends the idea that disability results from a biological dysfunction, which causes limitation and, as a consequence, a social barrier, being historically conceptualized in the context of its occurrence.

Today's society lives under an economic model that favors maximum productivity and supports the use of the perfect body as a work tool. Thus, attributes of inability are attached to the condition of disability, placing the subject in that situation at a disadvantage. In the ideals of productivity and efficiency, the difference represents holding off pre-established models, and those that are not in compliance with the standards are judged as deviant to society (Mike, 2013; Piccolo \& Mendes, 2017). Social groups eventually end up establishing disorders that may be considered 
as harmful or beneficial, or still, the ones that may cause depreciation or appreciation of the human being (Rossato \& Leonardo, 2011).

From a systematic review of the literature on the subject "disability", the importance of understanding its phenomenon as a social construct was established (added to the cultural-historical conception). It is implied, therefore, that no one is disabled by itself, but usually labeled on a social environment. This means recognizing diversity, however, disregarding it as a problem per se, but on the other hand, understanding the need for adjustments in functions of specific needs (Freitas \& Marques, 2010; Littig, Cárdia, Reis, \& Ferrão, 2012; Tijiboy \& Hogetop, 2001).

However, studies such as Tijiboy and Hogetop (2001) reaffirm the strong tendency of society to focus the subject's disability as arising from biological disorder. In other words, by acting in such a way, it is incurred that there is a serious risk to exempt the society's responsibility about the origin and worsening of disability - or about the disability condition preventing them from participating more actively in different areas. In the Brazilian scenario, only the last three decades demonstrated a concern to understand and recognize the rights of a disabled person like any other citizen, setting specific standards, in particular after the promulgation of the Constitution of 1988. It is not surprising, therefore, that society still connects feelings of charity and philanthropy to disabled people, barely believing in their productive possibilities. Synthesizing ideas, it is noticeable how people with disabilities are seen by society, that is, the majority of people who are not in this condition are responsible for guiding actions toward them.

Bearing in view such arguments, it is appropriate to determine the relationship between society and the concept of disability, a phenomenon of interest for Social Psychology. From this perspective, a survey was carried out in a post-doctoral study set up in a Scale for Conceptions of Disability Scale - SCD (Leite $\&$ Lacerda, 2018). Created in the light of theoretical and conceptual indicators, SCD guided the review of studies on the subject "disability and its relationship to society" from several Brazilian authors, many of which were based on the international literature available on the subject. It is a set of twenty sentences, which illustrates different ways of portraying disability, i.e. expressions filled with socially constructed meanings, indicating different opinions in relation to the disability phenomenon.

In order to improve the theoretical and methodological consistency of the resource, trying to avoid biased analysis, the statements of SDC were exposed to ten judges (researchers deeply experienced in studies related to the investigated theme). After some adjustments, we came to the concordance index $\mathrm{K}=0.83$, by Kappa test between judges and proponents of the scale, being considered by the consultants as a viable instrument to find out how people conceive the disability.

The SCD is composed of 20 statements which report the four conceptions of disability (organic, social, metaphysical and cultural-historical). The items were built in an affirmative way so that the participant indicates how much it is agreed with certain information. Some examples of items can be presented, such as "The lack of environmental conditions generate organic disabilities that deserve treatment" (social dimension); "Although disability is caused by different factors, it is centralized in the person with functional limitations" (biological dimension); "People with disabilities represent karma for events of other incarnations" (metaphysical dimension); "A person is considered less or more disabled depending on the context that is inserted" (historical-cultural dimension).

Each item of the scale consists of a statement followed by five possible answers, and the respondent shall, for each statement, choose one answer, which expresses a degree of agreement or disagreement over the proposed subject, as follows: a) totally agree; "b) partially agree; c) neither agree nor disagree; d) partially disagree; e) totally disagree. The third option (neither agree nor disagree) has been included, assuming the possibility that the participants might not understand the contents of the statement have no opinion about it or are not even willing to choose.

Currently, in addition to the evidence of validity based on content, it is in the process of validation through the inner structure with results that will be disclosed in future research. As for the reliability procedures, the scale already has a study through inter-rater reliability values, as mentioned in the previous paragraphs.

Reliability through time stability, according to Pritivera (2015), refers to how much time the instrument's data are constant during a period of time. It treats a psychometric procedure in which a single participant answer to an instrument twice. The interval between the applications must be structured by a way that does not impair the procedure, being recommended a gap from one to three months between them (test and retest).

One of the statistic methods to assess the time stability is the verification among the association of the results both in test and in retest. Then, correlation 
analysis can be used to verify this index of precision, being expected a strong association among the results in the two application phases, i.e., magnitude correlations over 0.70 (Groth-Marnat, 2009; Kline, 2000). In order to improve the psychometric parameters of the instrument with regard to accuracy, the present study will present the reviews that are consistent with the reliability of SCD (Leite \& Lacerda, 2018) by analyzing its temporal stability (test and retest).

As hypothesis 1, due to these two sample groups belong to the undergraduate courses of the human sciences, it is expected that the participants present greater scores in the categories related to the social and historical cultural dimensions of SCD; as hypothesis 2 , due to this study aims to verify the time stability of $\mathrm{SCD}$, strong correlations between test and retest phases are expected.

\section{Method}

\section{Data Collection Procedure}

The research report represented is the result of a larger project entitled "The cultural-historical psychology in understanding the concepts related to disability: An investigative analysis with future professionals", approved by the Research Ethics Committee (CAAE Protocol/Platform Brazil: No 13476713.5.0000.5398). The application of the scale (SCD) was performed with students from two courses - Public Relations and Journalism - a public university in the state of São Paulo. Courses and classes were chosen at random, according to the approval of professors (who previously agreed to allow that scales were applied during two of the subjects offered in both courses). It is important to highlight that the students had no prior knowledge about the application of the scale.

In both groups, at the end of the class, students were invited to participate of the research. Thus, the instrument was answered by university students who agreed to be part of the research after signing the Free and Clarified Consent Term (FCCT).

The first application of the scale in the classrooms took place in the first semester of 2015 and, on the occasion, there were 69 participants. Again, the scale was carried through after 30 days of first data collection. Students from both classes had no prior knowledge about the second application of the scale since it was only agreed between the researcher and the responsible professor. Not all students who responded to the first application of the scale attended their respective classes, on the date of the second application. On the second time,52 students responded to the scale, which resulted in a loss of $24.64 \%$ of participants, compared to the first data collection.

\section{Data Analysis Procedure}

In order to achieve the goal proposed by this study (analysis of reliability through temporal stability - test and retest) and, for purposes of data analysis, only the students who participated in both moments of the scale application were ranked. Based on this, the data was charted in the statistical program IBM SPSS Statistics Base and both descriptive and inferential statistical analysis were employed.

Descriptive statistics were used in order to reach the average scores obtained by participants in relation to the categories of the scale (Social, Biological, Metaphysics, and Historical-cultural), as well as in its entirety, to verify if there was a great difference in scores in both moments of the collection. With respect to inferential analysis, Pearson correlation between the two moments of the test and retest applications was requested, adopting as basis the significance level of $5 \%$, in order to observe whether the instrument, especially as a whole, presents a temporal stability, i.e., correlations with statistical significance were expected and with magnitudes ranging from moderate to severe. Data was collected in two undergraduate classes from different courses (Public Relations and Journalism) and the results and data shall be shown in its totality in both courses.

\section{Results}

The sample consisted of 52 university students aged 18 to 26 years old $(\mathrm{M}=20.17, \mathrm{SD}=1.89)$, mostly females $(n=33)$. With regard to the courses, 21 students attended the course of Public Relations and 31 attended Journalism. Following, in Table 1, the data containing the average of the responses in the categories of the SCD are presented as well as the resource as a whole, separated in relation to the researched courses, i.e. Public Relations and Journalism, allied to the data of the total sample (Public Relations + Journalism).

On Table 1, it is noticed that the average of the conceptions for the test and retest suffered minor variations, indicating that participants responded in a similar way, both in the first (test) and second (retest) application. More specifically, and confirming the hypothesis 1 , in the sample composed of students of Public Relations, the category related to questions regarding the cultural-historical conception was the one which presented the greatest differentiation, besides the scale as a whole. In the sample of Journalism, besides the total scale, the category consisting of issues related 
to social concept showed the greatest differentiation, and finally in the total sample, besides the total scale, the cultural-historical category was the one that showed greater differentiation.

TABLE 1

Averages in the conceptions of disability and in the scale as a whole

\begin{tabular}{lcc}
\hline Public Relations & Average (test) & Average (retest) \\
\hline Social & 2,06 & 1,84 \\
Biological & 1,62 & 1,50 \\
Metaphysics & 1,08 & 1,14 \\
Cultural-historical & 2,20 & 1,82 \\
Total SCD & 1,72 & 1,60 \\
\hline Journalism & Average (test) & Average (retest) \\
\hline Social & 2,28 & 2,04 \\
Biological & 1,68 & 1,78 \\
Metaphysics & 0,84 & 0,88 \\
Cultural-historical & 2,10 & 1,92 \\
Total SCD & 1,73 & 1,66 \\
\hline Total Sample & Average (test) & Average (retest) \\
\hline Social & 2,18 & 1,96 \\
Biological & 1,66 & 1,66 \\
Metaphysics & 0,94 & 0,98 \\
Cultural-historical & 2,14 & 1,88 \\
Total SCD & 1,72 & 1,64 \\
\hline & &
\end{tabular}

TABLE 2

Correlations (test and retest) of the concepts of disability and the scale as a whole

\begin{tabular}{lll}
\hline Public Relations & & \\
\hline Social (teste) & 0,30 & Social (retest) \\
Biological (test) & 0,13 & Biological (retest) \\
Metaphysics (test) & $0,86^{* *}$ & Metaphysics (retest) \\
Cultural-historical (test) & $0,68^{* *}$ & Cultural-historical (retest) \\
Total SCD (test) & $0,84^{* *}$ & Total SCD (retest) \\
\hline Journalism & & \\
\hline Social (test) & $0,53^{*}$ & Social (retest) \\
Biological (test) & 0,32 & Biological (retest) \\
Metaphysics (test) & $0,41^{*}$ & Metaphysics (retest) \\
Cultural-historical (test) & $0,63 * *$ & Cultural-historical (retest) \\
SCD Total (teste) & $0,75^{* *}$ & Total SCD (retest) \\
\hline Total Sample & & \\
\hline Social (test) & $0,45^{* *}$ & Social (retest) \\
Biological (test) & 0,24 & Biological (retest) \\
Metaphysics (teste) & $0,76^{* *}$ & Metaphysics (retest) \\
Cultural-historical (test) & $0,63^{* *}$ & Cultural-historical (retest) \\
SCD Total (test) & $0,77^{* *}$ & SCD Total (retest) \\
\hline
\end{tabular}

$* \mathrm{p}<0,05 ; * * \mathrm{p}<0,01$
It is possible to see by Table 2 that all correlations between test and retest, in the concepts of disability and on the scale as a whole, were positive. With regard to correlation with statistical significance between test and retest, irrespective of the sample, the total SCD presented significant correlations and above 0.70 . Through this data, it can be said that hypothesis 2 was also confirmed. As for the categories, the sample of Public Relations, the metaphysical conceptions $(\mathrm{r}=0.86)$ and cultural-historical $(\mathrm{r}=0.68)$ showed statistical significance; in the sample of Journalism, the SCD was statistically significant in social $(\mathrm{r}=0.53)$, metaphysics $(\mathrm{r}=0.41)$ and cultural-historical $(\mathrm{r}=0.63)$ categories, whereas in the total sample, the social categories $(r=0.45)$, metaphysics $(r=0.76)$ and cultural-historical $(\mathrm{r}=0.63)$ showed statistical significance.

\section{Discussion}

Disability tends to be linked by most of today's society, as the condition which refers to the idea of incapacity, placing the subject in this situation at a disadvantage (Baleotti \& Omote, 2014; Rossato \& Leonard, 2011). The way disability is conceived by society is not static, having a great variety of conceptions concerning disability over time (Freitas \& Marques, 2010).

In this study, the SCD was applied evaluating four different conceptions of disability - social, biological, metaphysical and cultural-historical. It was observed through the research that on average the highest scores listed by the participants were related to social and cultural-historical conceptions. In this regard, Baleotti \& Omote (2014), Mike (2013) and Omote (2018) point out that the social conception emerges based on production and maintenance by the society (understood as the result of the interpretation of the social environment). The other concept with the highest score in the study, cultural-historical, according to Leite (2017), on the interpretation of Vygotsky (1997), refers to disability as a reasoned dynamic and procedural process in the relationship between the individual and the socio-cultural context, which brings on a differentiated human development, adjustable according to the expectations and attitudes directed to it, namely it accrues in a biological dysfunction leading to limitation and, consequently, a social barrier.

From the general results in terms of averages, two discussions can be made. The first is linked to the fact that between the test and retest, there was no great variation among the responses of the subjects, which was already expected since even though the concepts 
on disability undergo modifications over time (Freitas \& Marques, 2010), it was not expected that this fact would occur with the sample studied, within a period of one month.

The second argument contradicts the findings of Tijiboy and Hogetop (2001). In other words, the concepts with higher averages in this study were social and cultural-historical, which is not consistent with the results found by the authors, because, according to them, the concept of disability which keeps permeating society is biological. It is possible to hypothesize from that result that, the higher education in the case of students of humanities, can contribute to a more critical view of disability (more focused on social and cultural-historical concept and less linked to biological and metaphysics concept).Such findings imply that the phenomenon of disability is considered broadly in which the context of its occurrence may or may not favor the participation of people with functional, sensorial or behavioral differences, that is, such differences may constitute impediments and/or disadvantages regarding how society is organized to attend them.

However, it is observable that there is a tendency of agreement with the biological perspective which implies in recognizing that the disability is centered in the body which represents itself, which means, it is understood as a failure or organic dysfunction. In line with this positioning, it is common to blame the subject for such condition.

Similar data were found by Baleotti and Omote (2014, p. 74), who applied the "Scale of Assessment for Conception of Disability", an instrument of selfauthorship, composed of 40 items, which also seeks to investigate conceptions of disability. In the study in question, the instrument was applied to 15 university professors with initial training in Occupational Therapy. In the data analysis it was observed that the respondents agreed more with statements than tried to explain the disability from a perspective of interaction, composed by constitutional and environmental factors, that is, "both limitations imposed by the pathology possessed by the individual and limitations or impediments that their surroundings can impose by restricting opportunities".

The fact that the sample of this study has been composed by academicals of the human sciences can be understood as a bias. In other words, the academic formation offered to those participants tends to direct to a more social and historical-cultural conception and, consequently, less biological and metaphysical about disability. Such a sample feature can be influenced both the mean score and the correlations in the two steps of the collect (test and retest). Then, the insertion of participants linked to courses of the biological sciences, for example, could confirm or not this assumption.

Discussing the disability issue is somewhat complex, but it is assumed that the central object of the study presented here was the temporal stability of a methodological instrument on conceptions of disability, which consisted of reliability analysis through test and retest of a scale. In addition, it was not the intention to ascertain the stability of the items of each of the conceptions, but rather the SCD in general, its entirety. For this, Pearson correlations were used in the total of the items, being observed that all associations were positive, mostly with statistical significance and magnitude ranging from moderate to severe. In terms of the total sample, the results of SDC, as a whole, showed a strong correlation $(\mathrm{r}=0.77)$ between the test and retest (Dancey \& Reidy, 2006). According to these authors, correlations with magnitudes until 0.39 are considered weak, whereas ones between 0.40 and 0.69 are moderate, and over 0.70 are classified as strong. As this research aimed to verify the time stability of the instrument, according to the formulated hypothesis, it was expected the found magnitude was strong - what, in fact, occurred

Based on Domino e Domino (2006), the analysis of the reliability test and retest is a procedure which aims to assess the consistency of results in the same instrument, after a time interval. For the author, it is important to draw attention for the period of time between the test and retest in order to avoid the socalled memory effect, also known as apprenticeship effect, which in case of specific instruments, such as intelligence, attention and memory, a short period of time for retesting may influence the result. The opposite is also true, since a very long period between the test and retest may lead to an underestimation of the temporal stability of the instrument. In this sense, aiming to minimize possible errors in the evaluation, we adopted the one-month interval between test and retest.

As to the rates considered appropriate by the specialized literature, Pasquali (2007), Prieto and Muniz (2000) and Groth-Marnat (2009), emphasize that values over 0.7 are considered acceptable for accurate analysis of instruments. This way, the reliability through test and retest for SDC was evidenced by the results given above. Specifically, using the statements of Cohen, Swerdlik and Sturman (2014), Hilsenroth and Segal (2004) and Zanon and Hauck Filho (2015), it can be said that the SCD, through test-retest reliability, obtained an estimate by the correlation of scores, which 
made it possible to verify the stability of the responses in the scale over time.

\section{Final considerations}

This study was to evaluate the reliability of SCD, a resource used to ascertain the conceptions of disability. For this purpose, a test and retest procedure was used to allow the investigation of whether similar results are obtained when the instrument is applied under the same methodological conditions, although they are applied at different times (in this case: thirty days). The results found were satisfactory and enabled the accomplishment of the proposed objectives; however, some findings in terms of limitations and suggestions for future studies are still needed.

Although the test and retest is a complex study, due to the fact that there is a loss in the sample, in regards to the limitations there should have been a larger number of participants. Moreover, other groups could be investigated, such as students enrolled in other courses, including other areas such as courses in natural and biological sciences areas. For future studies, it is suggested the implementation of the SDC with other instruments which investigate the phenomenon and which already have psychometric properties, in order to search for evidence of validity, for example, based on the relationship with other variables. However, after a sweep of the Brazilian literature of validated methodological instruments, it was only found the Inventory of Conceptions of Disability in Work Situations (ICD-ST) from Carvalho-Freitas (2012), though focused on the organizational context.

In terms of sampling in Brazil, by reading the document "Primer Census 2010 - People with Disabilities" (SDH-PR/SNPD, 2012), the number of people with disabilities represents 45.6 million, with impairment in at least one of the deficiencies investigated (visual, physical, hearing and intellectual), $8.3 \%$ of the Brazilian population had at least one type of severe disability. Thus, it shall be implied that it is necessary to invest in actions and research on the subject. Thereby, the SDC, due to its good reliability, is shown as a valid instrument to assess Brazilian disability conceptions. It can also assist in generating data. Its application in different groups, and in particular for professionals working with people with disabilities can indicate how they conceive this phenomenon, assisting in the restructuring of their professional practice, avoiding them to corroborate the idea of medicalization of some social problems. It is expected that the results of this study provide subsidies of interest for Social Psychology and for the investigated context itself, the public university, with a view to a more critical eye and less biased for segments of the population still heavily segregated.

\section{References}

Baleotti, L. R. \& Omote, S. (2014). A concepção de deficiência em discussão: ponto de vista de docentes de Terapia Ocupacional. Cadernos de Terapia Ocupacional da UFSCar, 22(1),71-78. https://doi.org/10.4322/cto.2014.008

Carvalho-Freitas, M. N. (2012). Validação do Inventário de Concepções de Deficiência em Situações de Trabalho (ICD-ST). Psico-USF, 17(1), 33-42. https://doi.org/10.1590/s1413-82712012000100005

Cohen, R. J., Swerdlik, M. E., \& Sturman, E. D. (2014). Testagem e avaliação psicológica: Introdução a testes e medidas ( $8^{\mathrm{a}}$ ed.). Porto Alegre: AMGH.

Dancey, C. P. \& Reidy, J. (2006). Estatística sem matemática para Psicologia: Usando o SPSS para Windows (3 $\underline{a}$ ed.). Porto Alegre: Artmed.

Domino, G. \& Domino, M. L. (2006). Psychological testing: An introduction (2nd ed.). Cambridge: Cambridge University Press. https://doi.org/10.1017/CBO9780511813757

Freitas, M. N. C. \& Marques, A. L. (2010). Inserção de pessoas com deficiência em organizações brasileiras: um estudo com empresas socialmente responsáveis. Revista Eletrônica de Gestão Organizacional, 8(3), 483-502. https://doi.org/10.1590/s1415-65552009000500009

Groth-Marnat, G. (2009). Handbook of psychological assessment (5th ed.). New York: Wiley.

Hilsenroth, M. J. \& Segal, D. L. (Ed.) (2004). Comprehensive handbook of psychological assessment (2nd ed., Vol. 2). New York: Wiley.

Kline, P. (2000). Handbook of psychological testing (2nd ed.). New York: Routledge. 
Leite, L. P. (2017). Relativizando o conceito de deficiência. In N. S. T. Leonardo, S. M. S. Barroco, \& S. P. M. Rossato (Orgs.), Educação especial e teoria histórico-cultural (pp. 35-43). Curitiba: Appris.

Leite, L. P. \& Lacerda, C. B. F. (2018). A construção de uma escala sobre as concepções de deficiência: Procedimentos metodológicos. Psicologia USP, 29(3), 432-441. https://doi.org/10.1590/0103-65642018109

Littig, P. M. C. B., Cárdia, D. R., Reis L. B., \& Ferrão E. S. (2012). Sexualidade na deficiência intelectual: Uma análise das percepções de mães de adolescentes especiais. Revista Brasileira de Educação Especial, 18(3), 469-486. https://doi.org/10.1590/s1413-65382012000300008

Mike, O. (2013). The social model of disability: Thirty years on. Disability \& Society, 28(7), 1024-1026. https://doi.or g/10.1080/09687599.2013.818773

Omote, S. (2004). Estigma no tempo da inclusão. Revista Brasileira de Educação Especial, 10(3), 287-308. Recuperado de http://www.abpee.net/homepageabpee04 06/artigos em pdf/revista10numero3pdf/3omote.pdf

Omote, S. (2018). Atitudes sociais em relação à inclusão: recentes avanços em pesquisa. Revista Brasileira de Educação Especial, 24, 21-32. https://doi.org/10.1590/s1413-65382418000400003

Pasquali, L. (2007). Validade dos testes psicológicos: será possível reencontrar o caminho? Psicologia: Teoria e Pesquisa, 23, 99-107. https://doi.org/10.1590/s0102-37722007000500019

Pessotti, I. (1984). Deficiência mental: Da superstição à ciência. São Paulo: T. A. Queiroz.

Prieto, G. \& Muñiz, J. (2000). Un modelo para evaluar la calidad de los tests utilizados em España. Papeles del Psicólogo, 77, 65-75. Recuperado de http://www.redalyc.org/pdf/778/77807709.pdf

Piccolo, G. M. \& Mendes, E. G. (2013). Contribuições a um pensar sociológico sobre a deficiência. Educação \& Sociedade, 34(123), 459-475. https://doi.org/10.1590/s0101-73302013000200008

Privitera, G. J. (2015). Research methods for the behavioral sciences (2nd ed.). New York: SAGE.

Resende, M. C. \& Gouveia, V. V. (2011). Qualidade de vida em adultos com deficiência física. Psicologia: Reflexão e Crítica, 24(1), 99-106. https://doi.org/10.1590/s0102-79722011000100012

Rossato, S. P. M. \& Leonardo, N. S. T. (2011). A deficiência intelectual na concepção de educadores da Educação Especial: contribuições da psicologia histórico cultural. Revista Brasileira de Educação Especial, 17(1), 71-86. https://doi.org/10.1590/s1413-65382011000100006

Tijiboy, A. \& Hogetop, L. (2001). Ressignificando a concepção de "deficiência" através de ambientes de aprendizagem computacionais telemáticos. Revista Educação Especial, (18), 93-105. https://doi.org/ $10.5902 / 1984686 \mathrm{X}$

Vygotski, L. S. (1997). Fundamentos da defectologia. In L. S. Vygotski, Obras escogidas (Tomo V). Madri: Visor.

Zanon, C. \& Hauck Filho, N. (2015). Fidedignidade. In C. S. Hutz, D. R. Bandeira, \& C. M. Trentini (Orgs.), Psicometria. Porto Alegre: Artmed.

Financiamento:

CNPq - Proc. 405787/2012-0 e Fapesp Proc. 2014/03811-2.

Agradecimento:

À Letícia Vicenzo Lourenço (responsável pela coleta dos dados - bolsista PIBIC na época da pesquisa).

Dados dos autores:

Lúcia Pereira Leite - Pós-Doutorado, Universidade Estadual Paulista (UNESP).

Hugo Ferrari Cardoso - Pós-Doutorado, Universidade Estadual Paulista (UNESP).

Endereço para correspondência:

Lúcia Pereira Leite

UNESP - Departamento de Psicologia

Av. Eng. Luiz Edmundo Carrijo Coube, 14-01 - Bairro Vargem Limpa

17033-360, Bauru, SP, Brasil

E-mail: lucialeite@fc.unesp.br

Recebido em: 31/01/2018.

Aceito em: 19/02/2019.

Publicado em: 05/08/2019. 